\title{
研究論文
}

\section{二段階燃焼合成法による $\mathrm{TiAl}$ 基， $\mathrm{Ni}_{3} \mathrm{Al}$ 基複合金属間化合物の相・組織と機械的性質}

\author{
平林 洋太郎 ${ }^{1}$, 竹内 慎二 $^{2}$, 日比野 敦 $^{3}$ \\ 1 富山県立大学工学部機械システム工学科, $=939-0398$ 射水市黒河 5180, \\ [現: (株) ヨロズ, テ 222-8560 横浜市港北区樽町 3-7-60]. \\ 2 富山県立大学大学院工学研究科機械システム工学専攻, 厂 939-0398 射水市黒河 5180, \\ [ 現: (株) 今仙電機製作所, $\bar{T} 484-8507$ 犬山市字柿畑 1]. \\ 3 富山県立大学工学部機械システム工学科, $=$ 9 939-0398 射水市黒河 5180.
}

\section{Synthesized Phases, Microstructure and Mechanical Properties of TiAl Base and $\mathrm{Ni}_{3} \mathrm{Al}$ Base Composite Intermetallic Compounds by Two-Step Combustion Synthesis}

\author{
Yotaro HIRABAYASHI ${ }^{1}$, Shinji TAKEUCHI ${ }^{2}$ and Atsushi HIBINO ${ }^{3}$ \\ ${ }^{1}$ Dept. of Mechanical Engineering, Inst. of Technology, Toyama Prefectural Univ., 5180 Kurokawa, Imizu 939-0398, Japan, \\ [Present Address: YOROZU CORPORATION, 3-7-60 Tarumachi, Kohoku, Yokohama 222-8560, Japan]. \\ ${ }^{2}$ Dept. of Mechanical System Engineering, Graduate School of Engineering, Toyama Prefectural Univ., 5180 Kurokawa, \\ Imizu 939-0398, Japan, [Present Address: Imasen Electric Industrial Co., Ltd., 1 Kakihata, Inuyama 484-8507, Japan]. \\ ${ }^{3}$ Dept. of Mechanical Engineering, Inst. of Technology, Toyama Prefectural Univ., 5180 Kurokawa, Imizu 939-0398, Japan.
}

Received March 10, 2014

\begin{abstract}
$\mathrm{TiAl}$ base and $\mathrm{Ni}_{3} \mathrm{Al}$ base composite intermetallic compounds were investigated by Two-step combustion synthesis process. In TiAl- $\mathrm{Ni}_{3} \mathrm{Al}$ composite compound by the combustion synthesis, the products contain $\mathrm{Ti}_{2} \mathrm{NiAl}_{3}\left(\tau_{3}\right)$ and $\mathrm{TiNi}_{2} \mathrm{Al}\left(\tau_{4}\right)$ phases, and spoil the mechanical properties of the composite compound material. Therefore, Twostep combustion synthesis of $\mathrm{TiAl}$ base and $\mathrm{Ni}_{3} \mathrm{Al}$ base composite compounds were examined in compositions near the $\mathrm{TiAl}$ and $\mathrm{Ni}_{3} \mathrm{Al}$ of the $\mathrm{Ti}-\mathrm{Ni}-\mathrm{Al}$ system.

Elemental $(\mathrm{Ti}+\mathrm{Al})$ premixed compact was made to react by thermal explosion reaction as first step combustion synthesis. The synthesized TiAl product was grinded, and mixed with elemental Ti, Ni and Al powders again. The $(\mathrm{TiAl}+\mathrm{Ti}+\mathrm{Ni}+\mathrm{Al})$ mixed compact was made to react by thermal explosion reaction as second step combustion synthesis. For the products obtained, density, phase, microstructure, Vickers hardness, and compression strength were measured.

By using Two-step combustion synthesis, $\mathrm{TiAl}$ base and $\mathrm{Ni}_{3} \mathrm{Al}$ base composite compounds could be fabricated. The TiAl base composite intermetallic compounds were so hard and so weak, to use for mechanical material. However $\mathrm{Ni}_{3} \mathrm{Al}$ base composite compounds contained a few Ti component exhibited superior ductility. Therefore, it was found that the addition of $\mathrm{Ti}$ component into $\mathrm{Ni}_{3} \mathrm{Al}$ is effective for improving the mechanical properties of $\mathrm{Ni}_{3} \mathrm{Al}$ compound.
\end{abstract}

\section{KEY WORDS}

combustion synthesis, reaction sintering, self-propagating high temperature synthesis, composite intermetallic compound, Titanium-Nickel-Aluminum

\section{1 緒言}

周知のように, 金属間化合物は既存の合金系材料に見られ ない特異な性質を示すことから, 高温構造材 ${ }^{1-4)}$ や形状記憶合 金 ${ }^{5)}$, 水素吸蔵合金 ${ }^{6}$, 磁性材料 ${ }^{7)}$, 超伝導材料 ${ }^{87}$, 生体材料 ${ }^{9)}$ 等, 様々な応用が期待されている. 中でも $\mathrm{TiAl} や \mathrm{Ni}_{3} \mathrm{Al}$ は, 高 温強度が室温下の強度よりも数倍高まる特異な性質から, 高 温用構造材としての用途が考えられている.しかし，依然と して実用化しないのは, $\mathrm{TiAl} や \mathrm{Ni}_{3} \mathrm{Al}$ の性質が脆く硬く, 材
料としての延性や靶性が不足するためである，かつ，これら 化合物を実使用する上で必要不可欠な, 製造方法や形状附与 の方法が見当たらないためである. 金属間化合物を実用化し， 普及を促進するためには, 金属間化合物の機械的性質を改善 し,かつ金属間化合物の材料プロセスを構築する必要がある.

上記背景から，著者らは二段階燃焼合成法による TiAl一 $\mathrm{Ni}_{3} \mathrm{Al}$ 系複合金属間化合物の製造を試みている ${ }^{10,11)}$.二段階燃 焼合成法とは，まず一段階目の燃焼合成で, TiAl, $\mathrm{Ni}_{3} \mathrm{Al}, \mathrm{NiTi}$ 
といった主要化合物を合成し，粉砕して化合物粉末を得る. 次いでこの化合物粉末に，さらに必要な $(\mathrm{Ti}+\mathrm{Ni}+\mathrm{Al})$ 要素粉 末を混ぜて二段階目の燃焼合成を行い, 目的化合物を得上う というものである. 燃燒合成反応を二段階に分けることで, 化合物の合成と粉研が繰返されて組織の微細化や均質化が図 れ,かつ要素粉末を燃焼合成させた場合で生じがちな, 反応熱 の過不足を軽減でき, 燃焼合成の熱的制御も容易になると期 待される. 既報では, TiAlや $\mathrm{Ni}_{3} \mathrm{Al}$ の延性や䩓性改善を目的と して, TiAl- $\mathrm{Ni}_{3} \mathrm{Al}$ 複合金属間化合物の燃焼合成を試みた ${ }^{10-12)}$. $(\mathrm{Ti}+\mathrm{Ni}+\mathrm{Al})$ 要素粉末からの単段の燃焼合成では反応熱の過不 足から，限られた組成範囲でしか健全な合成体が得られな かった ${ }^{12}$. これに対し，二段階燃焼合成法を採用することに より, 実験室レベルでは $\mathrm{Ti}-\mathrm{Ni}-\mathrm{Al}$ 三元系組成図の $\mathrm{TiAl}-\mathrm{Ni}_{3} \mathrm{Al}$ 線上での試料の燃焼合成が可能となった ${ }^{10,11}$. しかし，合成 体には $\mathrm{Ti}_{2} \mathrm{NiAl}_{3}\left(\tau_{3}\right)$ や $\mathrm{TiNi}_{2} \mathrm{Al}\left(\tau_{4}\right)$ といった脆く硬い相が生じ, 十分な機械的性質の合成体が得られなかった. そこで本研究 では, これら $\mathrm{Ti}_{2} \mathrm{NiAl}_{3}\left(\tau_{3}\right), \mathrm{TiNi}_{2} \mathrm{Al}\left(\tau_{4}\right)$ 等の脆弱な相の生成を 避けて, TiAl- $\mathrm{Ni}_{3} \mathrm{Al}$ 系金属間化合物を得る目的から, Ti-Ni-Al 三元系組成図の TiAl近傍, $\mathrm{Ni}_{3} \mathrm{Al}$ 近傍での燃焼合成を試みた。

\section{2 実験方法}

\section{1 一段階目 (TiAl 化合物粉末の作製)}

二段階燃焼合成法の主要なプロセスは, 既報と同じであ る ${ }^{10,11)}$. 原料粉末として, 平均粒径 $18 \sim 19 \mu \mathrm{m}$ の Ti 粉末 (東 邦チタニウム製), 平均粒径 $31 \mu \mathrm{m} の \mathrm{Ni}$ 粉末 (福田金属箔工業 製), 平均粒径 $1 \mu \mathrm{m}$ の $\mathrm{Al}$ 粉末 (東洋アルミニウム製) を使用 した. まず, $\mathrm{Ti}$ と $\mathrm{Al}$ の粉末を乳鉢で調合し, 金型を用い成形 圧力 $100 \mathrm{MPa}$ で圧密して, 円盤状 ( 直径 $\phi=25 \mathrm{~mm}$, 高さ $h=$
$7 \mathrm{~mm}$ )の TiAl混合粉末圧粉体を作製した. その際の混合比率 は, 原子比で $\mathrm{Ti}: \mathrm{Al}=1: 1$ とした. Fig. 1 亿, 真空電気炉の概 要図を示す. 圧粉体を試料台に乗せて石英管に入れ, 電気炉 にセットした. 石英管の内部を真空度 $5 \times 10^{-4} \mathrm{~Pa}$ 程度まで排 気した後, 炉を室温から $10^{\circ} \mathrm{C} / \mathrm{min}$ で昇温し, $700^{\circ} \mathrm{C}$ で 60 分 間保持して, 圧粉体に全体燃焼モードの燃焼合成反応を起こ させた. その際に，圧粉体の残留空気を除去するため，加熱 途中で $340^{\circ} \mathrm{C}, 15$ 分間の脱気工程を設けた. 得られた合成体 を, 乳鉢执よびボールミルを用いて粉砕し, 平均粒径 $33 \mu \mathrm{m}$ の TiAl 化合物粉末を作製した。

\section{2 二段階目 $\left(\mathrm{TiAl}-\mathrm{Ni}_{3} \mathrm{Al}\right.$ 系金属間化合物の作製 $)$}

一段階目で作製したTiAl粉末に, さらに $(\mathrm{Ti}+\mathrm{Ni}+\mathrm{Al})$ 要素粉 末を混合し, (TiAl)+(Ti+Ni+Al)混合粉末を作製した. Fig.2 (a) に, Ti-Ni-Al 三元組成図を示す. 二段階目の燃燒合成におい

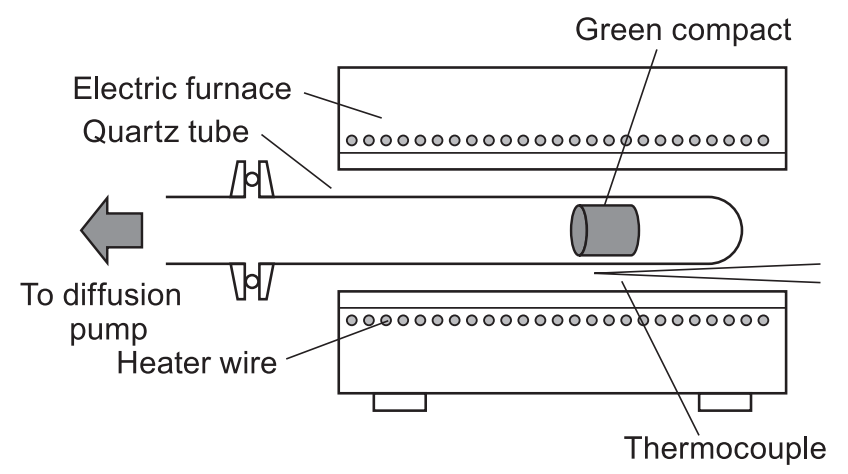

Fig. 1 Schematic drawing of vacuum furnace for combustion synthesis.

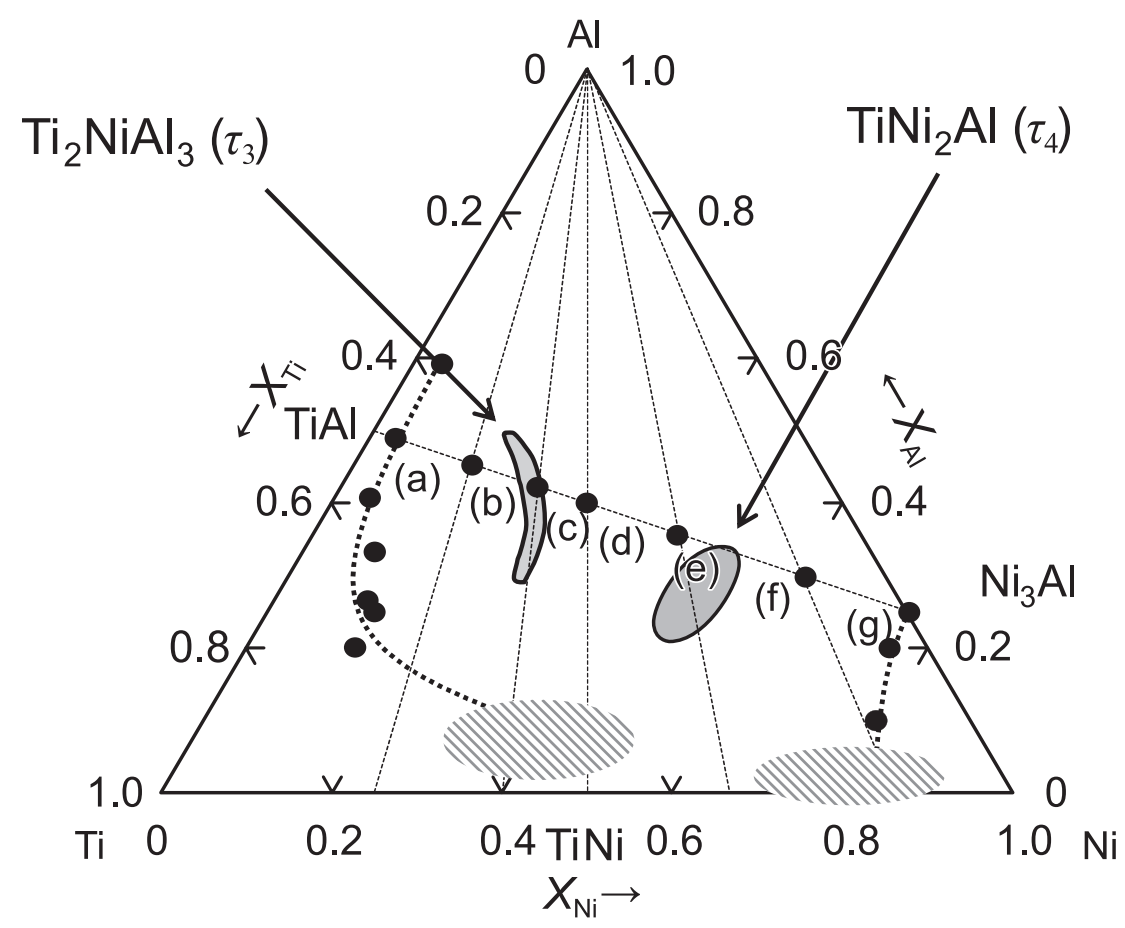

Fig. 2 (a) Ternary composition diagram of Ti-Ni-Al system. 
て目的とする組成は, $\mathrm{Ti}_{2} \mathrm{NiAl}_{3}\left(\tau_{3}\right)$ や $\mathrm{TiNi}_{2} \mathrm{Al}\left(\tau_{4}\right)$ といった 脆く硬い化合物を避ける目的から, Fig.2(a) の三元系組成図 の(a) (b) 間, (f) (g) 間とした. Fig.2 (b)に, Fig.2 (a)の TiAl 近傍の (a) (b) 間, $\mathrm{Ni}_{3} \mathrm{Al}$ 近傍の (f) (g) 間について, $\mathrm{Al}$ 分率 を縦軸にとり，直交軸で表した Ti-Ni-Al 三元系組成図を示 す. TiAl 近傍 (a) (b) 間の (o), (p), (q) 点, $\mathrm{Ni}_{3} \mathrm{Al}$ 近傍の (f) $(\mathrm{g})$ 間の $(\mathrm{r}),(\mathrm{s}),(\mathrm{t})$ 点について二段階目の燃燒合成を行った. 既報と同様に，一段階目の燃焼合成で作製した TiAl 粉末に, さらに $(\mathrm{Ti}+\mathrm{Ni}+\mathrm{Al})$ 要素粉末を混合し, 二段階目の燃焼合成 のための $(\mathrm{TiAl})+(\mathrm{Ti}+\mathrm{Ni}+\mathrm{Al})$ 混合粉末を作製した. その際に， $(\mathrm{TiAl})+(\mathrm{Ti}+\mathrm{Ni}+\mathrm{Al})$ 混合粉末のうち, Ti 粉末およびAl粉末を 減らし, 代わりにTiAl粉末を加えて, 燃焼合成の反応熱量を 調整した. この混合粉末を金型で圧密し(成形圧力 $100 \mathrm{MPa}$ ), 円柱状の圧粉体 (直径 $\phi=16 \mathrm{~mm}$, 高さ $h=16 \mathrm{~mm}$ ) を作製した. この圧粉体を真空電気炉に入れ，内部を $5 \times 10^{-4} \mathrm{~Pa}$ 程度まで 排気した後, 炉を室温から $10^{\circ} \mathrm{C} / \mathrm{min}$ で昇温し, 60 分間保持 して合成体を得た。なお圧粉体が含む残留空気を除去するた め, 一段階目と同様に, 昇温途中で $340^{\circ} \mathrm{C}, 15$ 分間の脱気工 程を設けた. 得られた合成体について, 密度測定, 組織観察, $\mathrm{X}$ 線分析, SEM-EDX 分析, ビッカース硬度試験，および圧 縮試験を行った。

\section{3 実験結果および考察}

Fig. 3に, 一段階目の燃焼合成のTi/Al混合粉末圧粉体, TiAl 合成体，ならびにその合成体を粉砕した粉末の外観を示す. 既報のように，一段階目の燃焼合成によって，TiAl合成体が 得られた．また，この TiAl合成体を乳鉢で粉䂶すると，平均 粒径 $33 \mu \mathrm{m}$ の微細な TiA1 粉末が得られた ${ }^{10)}$.この粉末につい てX線分析を行うと, この粉末は $\mathrm{TiAl}, \mathrm{Ti}_{3} \mathrm{Al}$ 化合物である
ことが分かった. そこで，この(TiAl)粉末に，(Ti+Ni+Al)の 要素粉末を混ぜて燃焼合成を行い, Fig.2 (b) の (o), (p), (q) 点 ならびに $(\mathrm{r}),(\mathrm{s}),(\mathrm{t})$ 点の燃焼合成を行った.

Fig.4に, (o) 点に扔いて, 二段階目の燃焼合成を行った結 果を示す. (Ti+Al)要素粉末は燃焼合成の際に反応熱を放出す るので, $(\mathrm{TiAl})+(\mathrm{Ti}+\mathrm{Ni}+\mathrm{Al})$ 混合粉末では $(\mathrm{Ti}+\mathrm{Al})$ 粉末が多 いほど, 二段階目の燃焼合成の反応熱量は多い。 逆に, (TiAl)+ $(\mathrm{Ti}+\mathrm{Ni}+\mathrm{Al})$ 混合粉末に含まれる( $\mathrm{Ti}+\mathrm{Al})$ 粉末を減らし, (TiAl) 粉末を増やせば反応熱量は減ることになる，そこで (TiAl)+ $(\mathrm{Ti}+\mathrm{Ni}+\mathrm{Al})$ 混合粉末のうち, $(\mathrm{Ti}+\mathrm{Al})$ 粉末と $(\mathrm{TiAl})$ 化合物粉 末量の割合を変化させつつ, 二段階目の燃焼合成を行った。 図の様に, (Ti+Al)粉末を減らし, (TiAl)粉末が多いと熱量が 不足し, 燒結収縮が不足した. 逆に, (Ti+Al) 粉末を増やし, (TiAl)粉末を減らした場合では, 反応熱が過剩となり, 合成体 が融解し始め, 圧粉体の残留空気も関係して, 側面には笠 が入った. $(\mathrm{Ti}+\mathrm{Al})$ 粉末と (TiAl)粉末の量を制御しながら燃焼 合成を繰り返した結果, (o) 点を構成するのに必要な $(\mathrm{TiAl})+$ $(\mathrm{Ti}+\mathrm{Ni}+\mathrm{Al})$ 混合粉末のうち, 原子比で $(\mathrm{Ti}+\mathrm{Al})$ 粉末を約 $90 \sim$

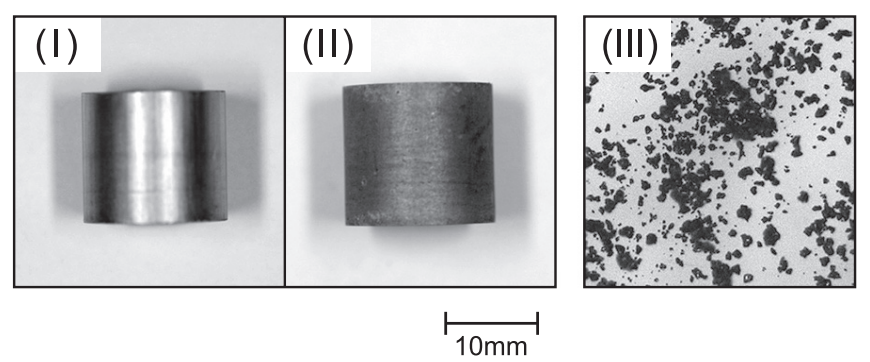

Fig. 3 Appearance of green compact and synthesized product, and macro view of TiAl powder (Particle size: $33 \mu \mathrm{m}$ ).

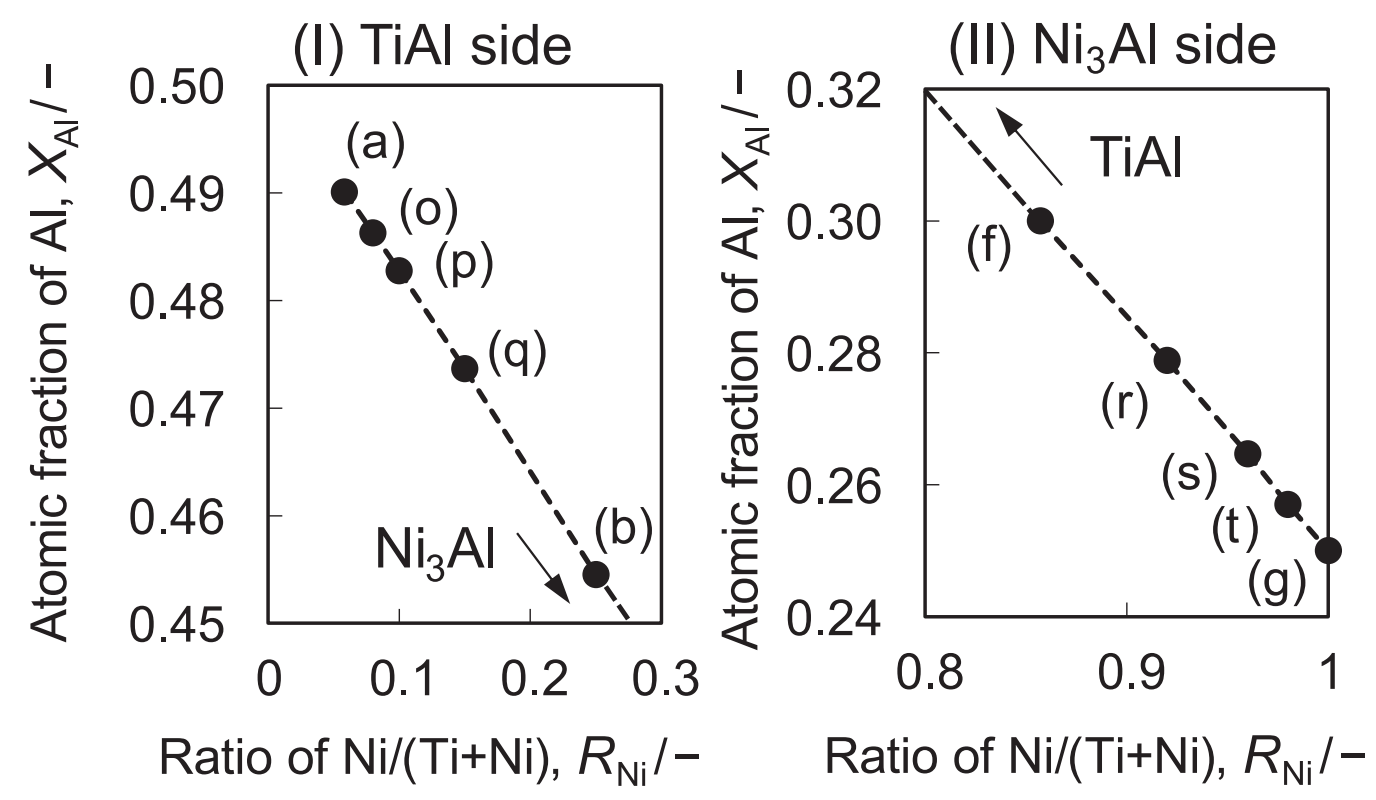

Fig. 2 (b) Ternary composition diagram of Ti-Ni-Al system around $\mathrm{TiAl}$ and $\mathrm{Ni}_{3} \mathrm{Al}$ compounds, (I) TiAl side, (II) $\mathrm{Ni}_{3} \mathrm{Al}$ side. 
Point (0). $\mathrm{Ni} /(\mathrm{Ti}+\mathrm{Ni})=0.08$

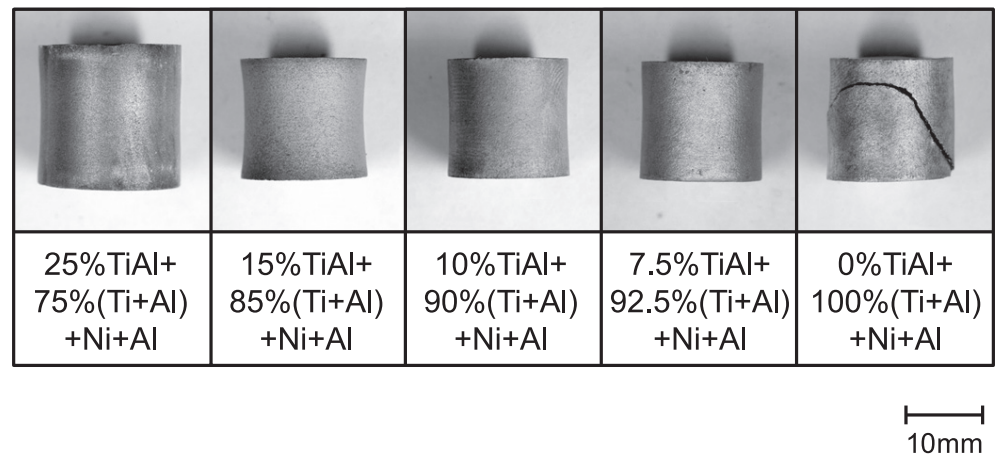

Fig. 4 Change of synthesized products of point (o) with controlling of $(\mathrm{TiAl}) /(\mathrm{Ti}+\mathrm{Al})$ ratio.

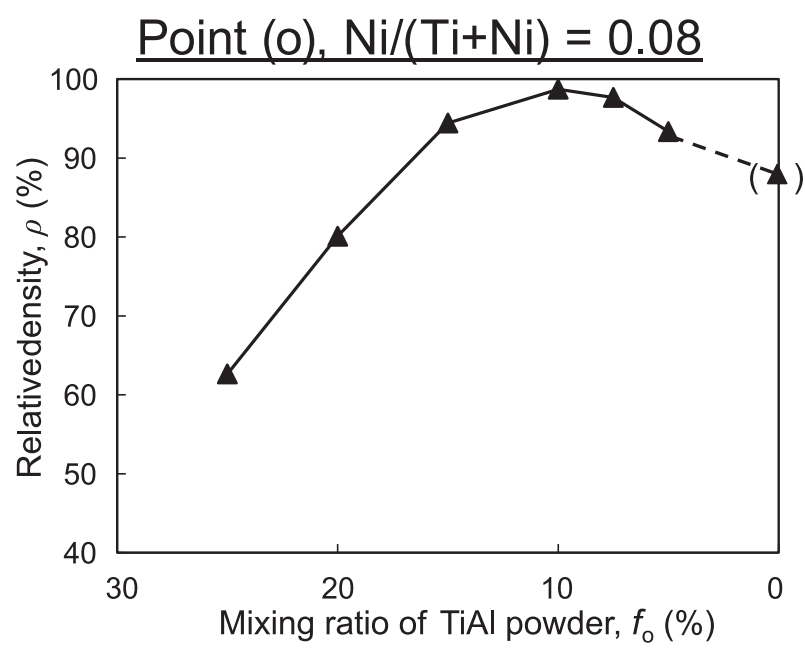

Fig. 5 Change of relative density of point (o) with controlling of $(\mathrm{TiAl}) /(\mathrm{Ti}+\mathrm{Al})$ ratio.

92.5\%, (TiAl) 粉末を 10〜 7.5\% (ただし (Ti+Al) 粉末と (TiAl) 粉末の和は $100 \%)$ とすれば焼結収縮が観察され，健全な合成 体が得られることが分かった。

Fig.5に, Fig.4の試料の相対密度を示す. (o) 点を構成する のに必要な $(\mathrm{TiAl})+(\mathrm{Ti}+\mathrm{Ni}+\mathrm{Al})$ 混合粉末のうち, $(\mathrm{Ti}+\mathrm{Al})$ 粉 末と(TiAl)粉末量を制御することで密度が高まることが分か る.この図から，原子比で $(\mathrm{Ti}+\mathrm{Al})$ 粉末を約 $90 \%$, ( TiAl) 粉 末を $10 \%$ とすれば, 密度が最も高まることがわかった。

Fig.6に, 同様にして (p), (q)点で二段階目の燃焼合成を行っ た結果を示す.いずれも密度が $90 \%$ 以上となり, 緻密な合成 体が得られた. また, 組織は, $10 \sim 20 \mu \mathrm{m}$ 程度の結晶粒の複 合組織から成ることが分かった。

$\mathrm{TiAl}$ 近傍の $(\mathrm{o}),(\mathrm{p}),(\mathrm{q})$ 点と同様にして, $\mathrm{Ni}_{3} \mathrm{Al}$ 近傍 $(\mathrm{f}) \sim(\mathrm{g})$ 間の(f), (r), (s), (t) 点について, 二段階目の燃焼合成を試みた. (t) 点は, 上記と同様の方法で合成体が作製できた。 しかし， (f), (r), (s) 点では合成体が溶岩状に融解した。 Fig. 7 に，二段 階目の燃焼合成を(f)点で行った結果を示す. (f) 点を構成する のに必要な $(\mathrm{TiAl})+(\mathrm{Ti}+\mathrm{Ni}+\mathrm{Al})$ 混合粉末のうち $(\mathrm{Ti}+\mathrm{Al})$ 粉末

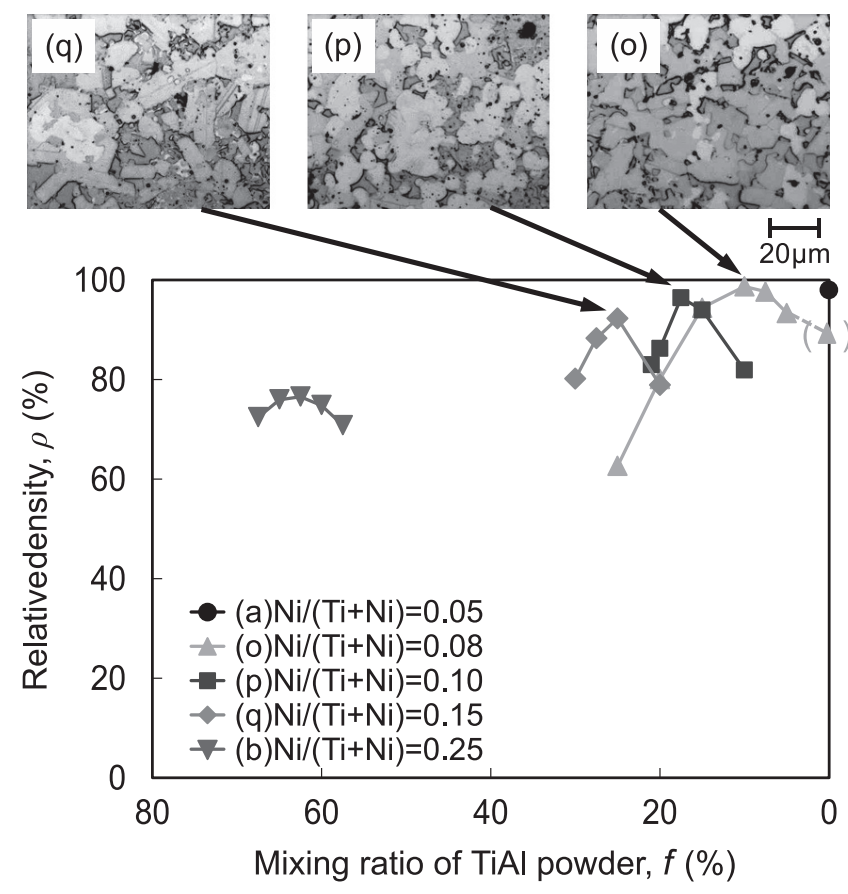

Fig. 6 Relative densities of synthesized products for points (a), (o), (p), (q) and (b).

と $(\mathrm{TiAl})$ 粉末量を変化させながら，二段階目の燃焼合成を 行った. しかし, (f) 点を構成するのに必要な $(\mathrm{TiAl})+(\mathrm{Ti}+\mathrm{Ni}+$ $\mathrm{Al})$ 混合粉末のうち, 全ての $(\mathrm{Ti}+\mathrm{Al})$ 粉末を $(\mathrm{TiAl})$ 粉末に置き 換えても, 合成体が溶岩状に溶け, 二段階目の燃燒合成が出 来ないことが分かった。

そこで, 二段階目の燃焼合成を行う際に, (f), (r), (s) 点を構 成するのに必要な $(\mathrm{TiAl})+(\mathrm{Ti}+\mathrm{Ni}+\mathrm{Al})$ 混合粉末のうち, $\mathrm{Al}$ 粉 末量を減らし, 二段階目の燃焼合成を試みた. (f), (r), (s) 点を 構成するに必要な $\mathrm{Ti}, \mathrm{Ni}, \mathrm{Al}$ のモ儿数を, 例えば $x n_{\mathrm{Ti}}: y n_{\mathrm{Ni}}$ : $z n_{\mathrm{Al}}$ とする. $(\mathrm{TiAl})+(\mathrm{Ti}+\mathrm{Ni}+\mathrm{Al})$ 混合粉末のうち, fの割合で $(\mathrm{Ti}+\mathrm{Al})$ 粉末を $(\mathrm{TiAl})$ 粉末に置き換えた場合では, $\mathrm{Ti}, \mathrm{Ni}, \mathrm{Al}$, TiA1のモル数は, $x(1-f) n_{\mathrm{Ti}}: y n_{\mathrm{Ni}}:(z-x f) n_{\mathrm{Al}}: x f n_{\mathrm{TiAl}}$ となる. Fig.6のように, (f), (r), (s) 点の $(\mathrm{TiAl})+(\mathrm{Ti}+\mathrm{Ni}+\mathrm{Al})$ 混合粉末 


\section{Point (f), $\mathrm{Ni} /(\mathrm{Ti}+\mathrm{Ni})=0.86$}

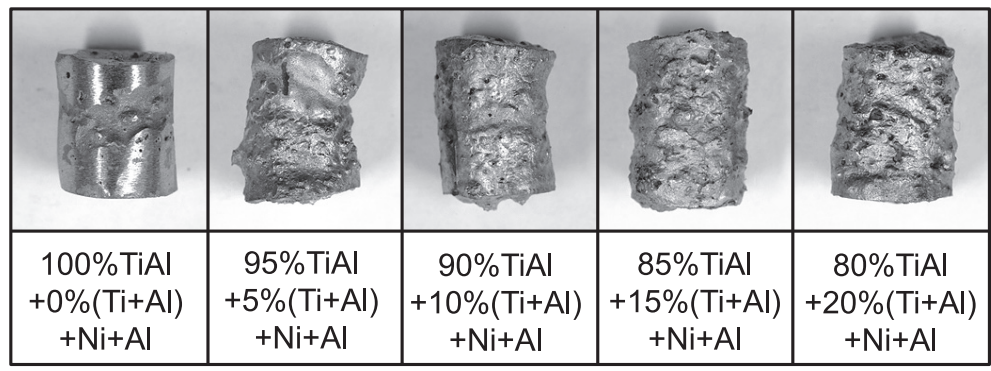

$$
\stackrel{\longmapsto}{10 \mathrm{~mm}}
$$

Fig. 7 Change of synthesized products of point (f) with controlling of $(\mathrm{TiAl}) /(\mathrm{Ti}+\mathrm{Al})$ ratio.

Point $(r), \mathrm{Ni} /(\mathrm{Ti}+\mathrm{Ni})=0.92$

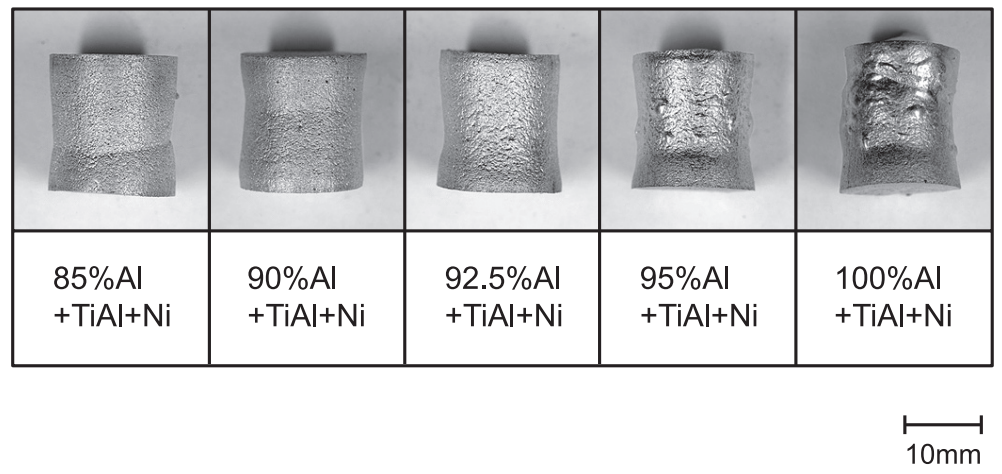

Fig. 8 Change of synthesized products of point (r) with controlling of Al ratio.

の全ての $(\mathrm{Ti}+\mathrm{Al})$ 粉末を $(\mathrm{TiAl})$ 粉末を置き換えた場合 $(f=1)$ で も合成体が溶岩状に融解するので,さらにAl量を減らして燃 焼合成させた。即ち，

$$
\begin{aligned}
& n_{\mathrm{Ti}}: y n_{\mathrm{Ni}}: 1.000(z-x) n_{\mathrm{Al}}: x n_{\mathrm{TiAl}}(f=1) \\
& n_{\mathrm{Ti}}: y n_{\mathrm{Ni}}: 0.950(z-x) n_{\mathrm{Al}}: x n_{\mathrm{TiAl}}(f=1) \\
& n_{\mathrm{Ti}}: y n_{\mathrm{Ni}}: 0.925(z-x) n_{\mathrm{Al}}: x n_{\mathrm{TiAl}}(f=1) \\
& n_{\mathrm{Ti}}: y n_{\mathrm{Ni}}: 0.900(z-x) n_{\mathrm{Al}}: x n_{\mathrm{TiAl}}(f=1) \\
& n_{\mathrm{Ti}}: y n_{\mathrm{Ni}}: 0.850(z-x) n_{\mathrm{Al}}: x n_{\mathrm{TiAl}}(f=1)
\end{aligned}
$$

として二段階目の燃焼合成を試みた. Fig. 8に, その結果を示 す. Al 量を減らすにつれ，合成体が溶岩状になるのが防げる ことが分かる.

Fig.9に，これら合成体の密度を示す. $\mathrm{Al}$ 粉末量を制御する ことで, 密度を高められることが分かる. (r), (s) 点について も同様に $\mathrm{Al}$ 粉末量を制御した結果, Fig. 10 のように, 密度 85〜92\%程度のほぼ緻密な合成体が得られた. (f), (r), (s) 点 では, A1 量を減らして燃焼合成させているので, Fig. 2 (a)の $\mathrm{Ti}-\mathrm{Ni}-\mathrm{Al}$ 系三元系組成図では, TiAl- $\mathrm{Ni}_{3} \mathrm{Al}$ 線から若干, 下方 に組成をシフトしたことになる。一方で, (t) 点は, 特に $\mathrm{Al}$ 量 を調整せずに，健全な合成体が得られた。

Fig. 11 に, TiAl 近傍の (o), (q) 点, および $\mathrm{Ni}_{3} \mathrm{Al}$ 近傍の (r), (t) 点の合成体の X 線分析結果を示す.いずれも原料粉末の

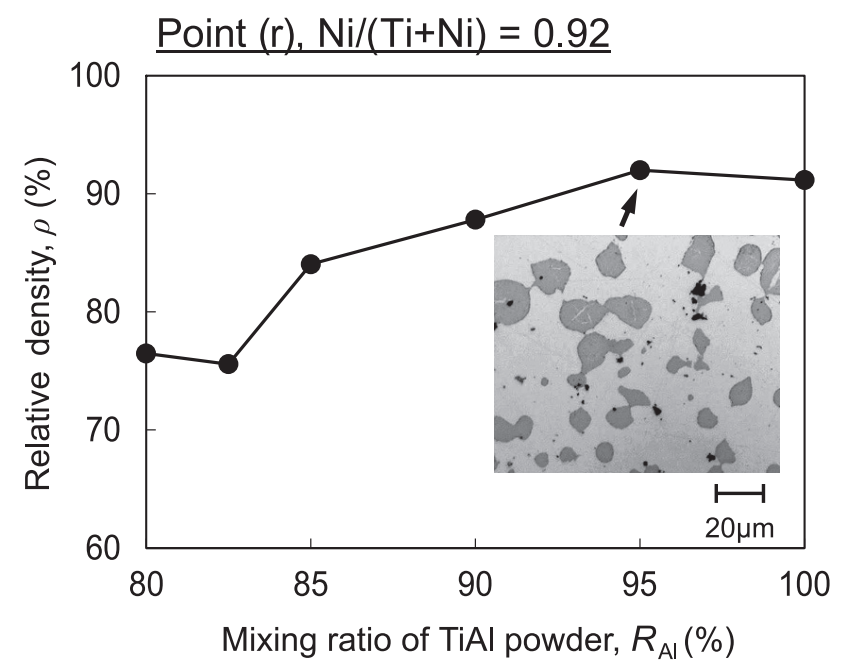

Fig.9 Change of relative density of point (r) with controlling of $\mathrm{Al}$ ratio.

ピークが消え, 代わって化合物のピークが現れることが分か る。すなわち燃焼合成により化合物が合成されることが分か る. X 線回折の結果, TiAl 近傍の (o), (q) 点では, TiAl 相+ 


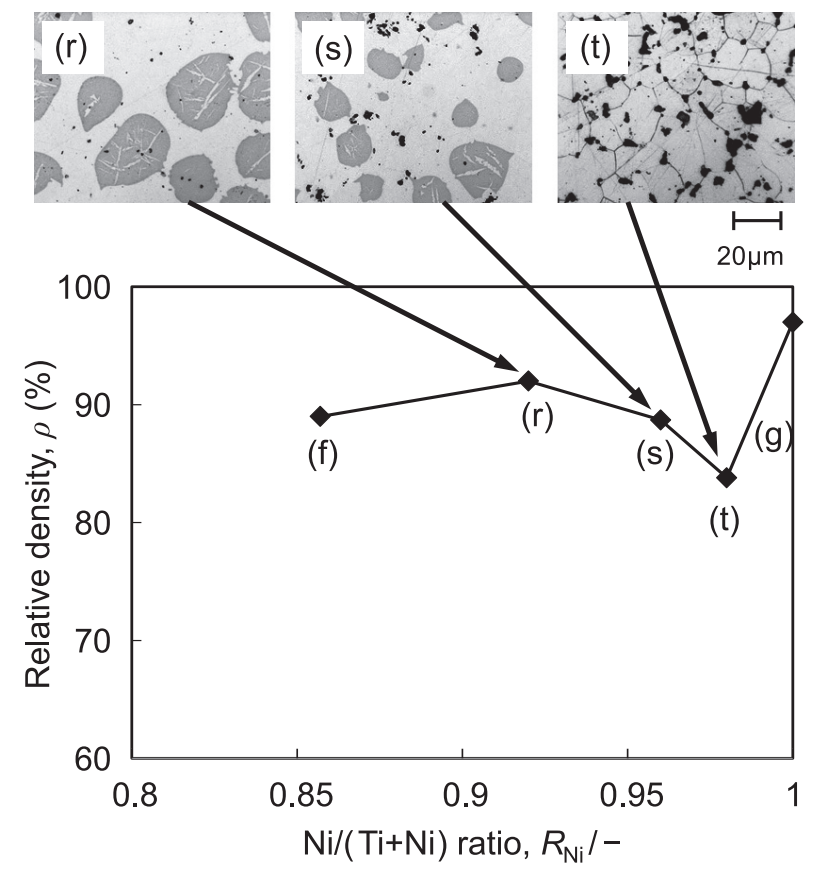

Fig. 10 Relative densities of synthesized products of points (f), (r), $(\mathrm{s}),(\mathrm{t})$ and $(\mathrm{g})$.

$\mathrm{Ti}_{3} \mathrm{Al}+\mathrm{Ti}_{2} \mathrm{NiAl}_{3}\left(\tau_{3}\right)$ 相が, また $\mathrm{Ni}_{3} \mathrm{Al}$ 近傍の $(\mathrm{r}),(\mathrm{s})$ 点では $\mathrm{Ni}_{3} \mathrm{Al}$ 相 $+\mathrm{NiAl}$ 相から成り, (t) 点は, $\mathrm{Ni}_{3} \mathrm{Al}$ 単相から成ることが分 かった。

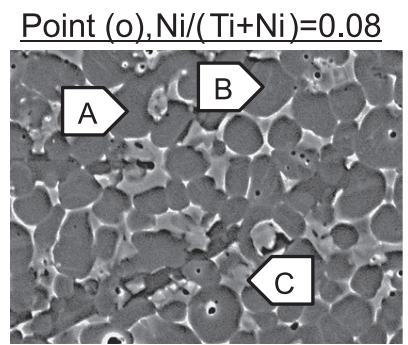

A:TiAl, B:Ti ${ }_{3} \mathrm{Al}, \quad \mathrm{C}: \mathrm{Ti}_{2} \mathrm{NiAl}_{3}\left(\tau_{3}\right)$

Point $(p), \mathrm{Ni} /(\mathrm{Ti}+\mathrm{Ni})=0.10$

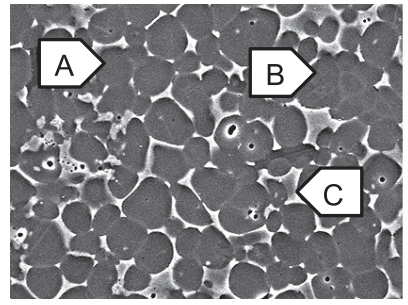

A:TiAl, B:Ti ${ }_{3} \mathrm{Al}, \quad \mathrm{C}: \mathrm{Ti}_{2} \mathrm{NiAl}_{3}\left(\tau_{3}\right)$

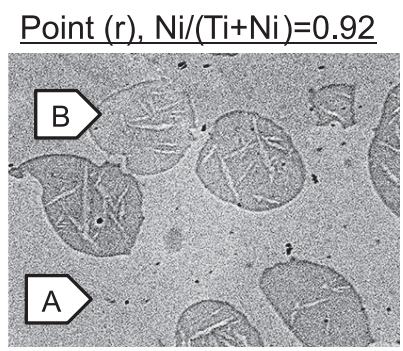

$\mathrm{A}: \mathrm{Ni}_{3} \mathrm{Al}, \mathrm{B}: \mathrm{NiAl}$

Point $(\mathrm{t}), \mathrm{Ni} /(\mathrm{Ti}+\mathrm{Ni})=0.98$

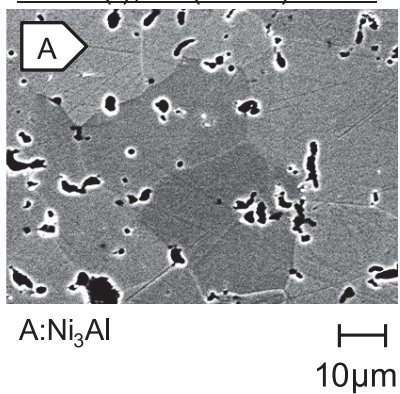

Fig. 12 SEM-EDX analyses of synthesized products of points (o), $(\mathrm{p}),(\mathrm{r})$ and $(\mathrm{t})$.

Fig. 12 に, TiAl 近傍の (o), (p) 点, $\mathrm{Ni}_{3} \mathrm{Al}$ 近傍の $(\mathrm{r}),(\mathrm{t})$ 点の SEM-EDX 分析による相同定の結果を示す. TiAl近傍 (o), (p) 点は, 粒径約 $10 \sim 15 \mu \mathrm{m}$ の液相焼結組織からなる. EDX 分析

Point $(r), \mathrm{Ni} /(\mathrm{Ti}+\mathrm{Ni})=0.92$
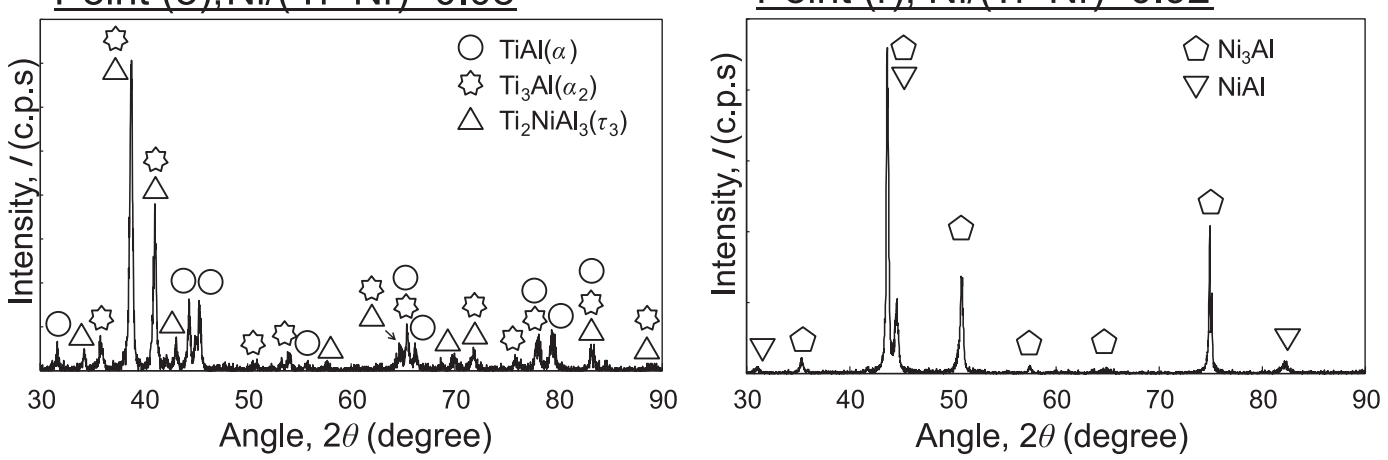

Point $(\mathrm{q}), \mathrm{Ni} /(\mathrm{Ti}+\mathrm{Ni})=0.15$
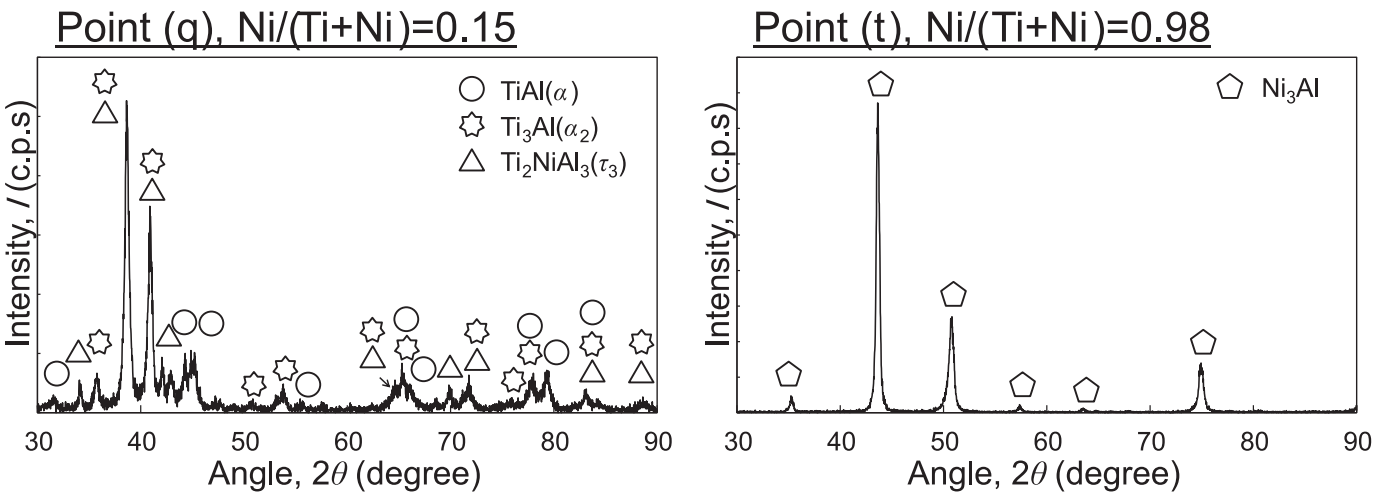

Fig. 11 X-ray analyses of synthesized products of points (o), (q), (r) and (t). 
から,これらは $\mathrm{TiAl}$ 相 $+\mathrm{Ti}_{3} \mathrm{Al}$ 相 $+\mathrm{Ti}_{2} \mathrm{NiAl}_{3}\left(\tau_{3}\right)$ 相と分かった. 一方, $\mathrm{Ni}_{3} \mathrm{Al}$ 側の $(\mathrm{r}),(\mathrm{s})$ 点では, $\mathrm{Ni}_{3} \mathrm{Al}$ 相 $+\mathrm{NiAl}$ 相からなる複 合組織, ( $\mathrm{t}$ ) 点は $\mathrm{Ni}_{3} \mathrm{Al}$ 単相から成ることが分かった.これら 相は, X線分析, SEM-EDX分析ともに, Ti-Ni-Al 系状態図 ${ }^{13)}$ とほぼ対応した。

Fig. 13 に, TiAl 近傍の (a)〜 (b) 間の (o), (p), (q) 点, ならび に $\mathrm{Ni}_{3} \mathrm{Al}$ 近傍の $(\mathrm{f}) \sim(\mathrm{g})$ 間の $(\mathrm{r}),(\mathrm{s}),(\mathrm{t})$ 点のマイクロビッカー 又硬度を示す. 負荷条件は $50 \mathrm{~g}, 30 \mathrm{~s}$ とした. TiAl 近傍では, $\mathrm{Ni} /(\mathrm{Ti}+\mathrm{Ni})$ 比が増えるにつれ, 硬度は増した. Ni/(Ti+Ni) 比 が増えるにつれ硬度が増すことから, 合成体の機械的性質が 硬く脆くなることが推測できる. $\mathrm{Ni}_{3} \mathrm{Al}$ 近傍では, $(\mathrm{f}) \sim(\mathrm{g})$ 間 の (r), (s), (t) 点でも同様に, Ni/(Ti+Ni) 比が減るにつれ, 硬度 は増した. しかし $(\mathrm{t})$ 点は, $(\mathrm{g})$ 点とおよそ同程度の硬度であ り，その機械的性質は硬く脆くならないことが示唆された.

Fig. 14 に, TiAl 近傍の (a), (o), (p) 点, ならびに $\mathrm{Ni}_{3} \mathrm{Al}$ 近傍 の $(\mathrm{s}),(\mathrm{t}),(\mathrm{g})$ 点の圧縮試験の結果を示す. (a) 点の圧縮強度試 験結果は, 以前, 著者らが測定した結果である ${ }^{14)}$. TiAl 近傍 の (a), (o), (p) 点の比較では, (a) 点が最も強度, 延性に優れて いた. (o), (p) 点は, 合成体が脆く硬く, 強度が著しく低い. 従って, TiAlにNiを多量に添加した場合, 合成体の機械的性 質に対し，悪影響があることが分かる。

一方, $\mathrm{Ni}_{3} \mathrm{Al}$ 近傍の $(\mathrm{s}),(\mathrm{t}),(\mathrm{g})$ 点の比較では, $(\mathrm{g})$ 点より $(\mathrm{s})$, (t)点の方が圧壊ひずみに優れていた. $(\mathrm{g})$ 点では, 圧壊ひずみ は 13\%〜19\%であった. なお圧壊ひずみ $13 \%$ の曲線は，以 前の著者らのデーターの再掲 ${ }^{15)}$ であり, $19 \%$ の曲線が今回, 再測定したデーターである.これに対して，(s)点では圧壊ひ ずみが $22 \%,(\mathrm{t})$ 点では圧壊ひずみが $23 \sim 26 \%$ を示し, $\mathrm{Ni}_{3} \mathrm{Al}$ にTiを添加することで, 延性が改善できることが分かった. ただし,この結果は僅か数個の試料から得た結果であり, 試 料の出来, 不出来によっても左右されがちである. 従って, 本 結果については今後も検討を必要とする.
Fig. 15に, 圧縮試験後の合成体の外観を示す. TiAl 近傍の (o), (p) 点では, 合成体が脆く硬く, 殆ど変形を生じないまま 試料に縦亀裂が生じた。圧縮試験では, 試験片の円周方向の 引張応力を生じることから, (o), (p) 点の試料が脆く, 引張応 力に弱いことが分かる.X線分析やSEM-EDX 分析では, (o), (p) 点では $\mathrm{TiAl}$ 相, $\mathrm{Ti}_{3} \mathrm{Al}$ 相に加え, $\mathrm{Ti}_{2} \mathrm{NiAl}_{3}\left(\tau_{3}\right)$ 相の生成が確 認された。 (a)点では圧縮試験において, (o), (p) 点のような亀 裂は生じないので ${ }^{14)}, \mathrm{TiAl}$ 多量のNiを添加したことに伴う $\mathrm{Ti}_{2} \mathrm{NiAl}_{3}\left(\tau_{3}\right)$ 相が, (o), (p) 点の脆さの原因と考えられる.

一方, $\mathrm{Ni}_{3} \mathrm{Al}$ 近傍では, $(\mathrm{g})$ 点は圧縮試験により脆く圧壊し た.これに対して, Tiを含む $(\mathrm{s}),(\mathrm{t})$ 点では, $(\mathrm{g})$ 点のような全体 の圧壊が避けられ, 側面の微小亀裂に留まっている. 圧縮試 験片の外観からも $\mathrm{Ni}_{3} \mathrm{Al} へ$ Ti 添加が有効なことが分かっ た (なお,この Fig.15の試験片では, 圧壊状態がマク口写真 で明瞭に判別できるよう, 圧壊後も余分に加圧している).

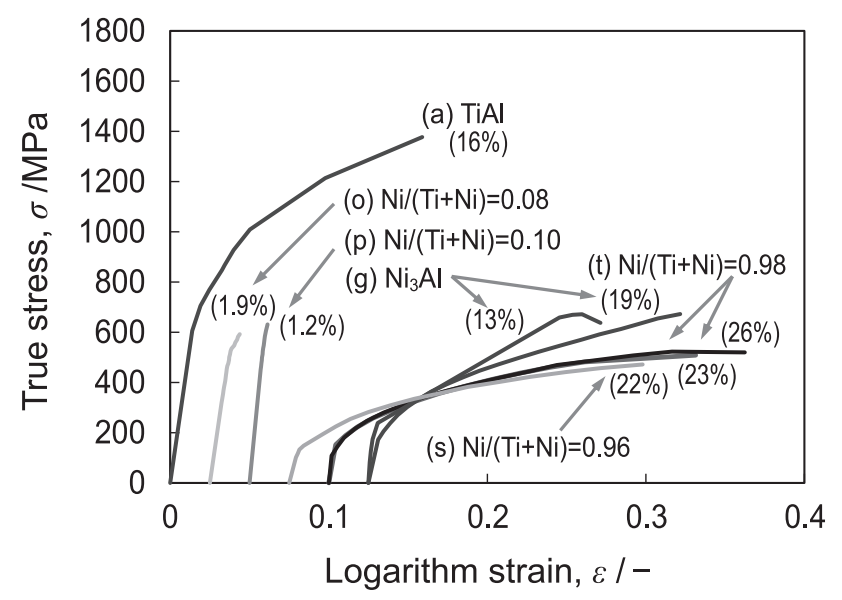

Fig. 14 Stress-strain curves of synthesized products (Compression test).

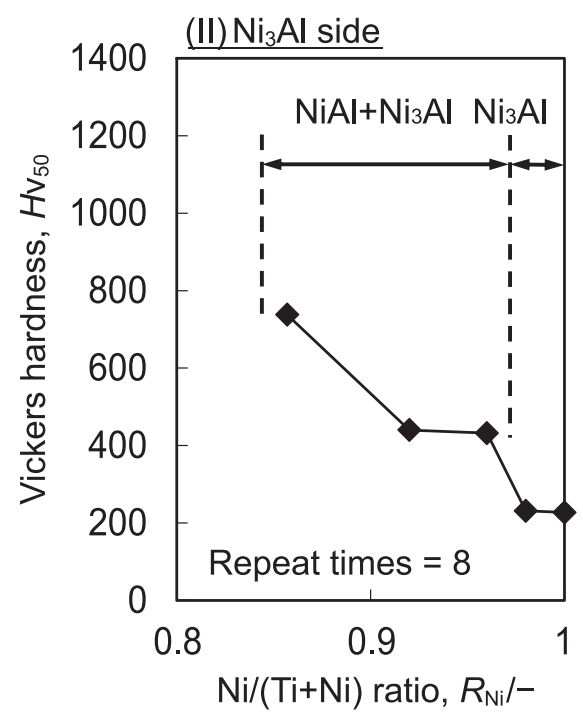

Fig. 13 Vickers hardness of synthesized products, (I) TiAl side, (II) $\mathrm{Ni}_{3} \mathrm{Al}$ side. 


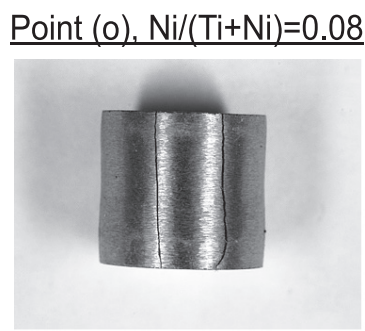

Fracture strain, $\varepsilon_{\mathrm{f}}=1.9 \%$

Point $(\mathrm{p}), \mathrm{Ni} /(\mathrm{Ti}+\mathrm{Ni})=0.10$

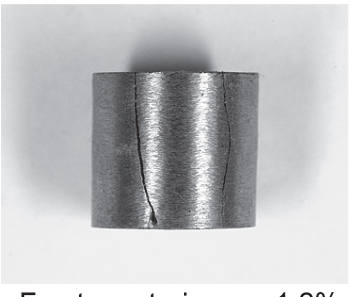

Fracture strain, $\varepsilon_{\mathrm{f}}=1.2 \%$

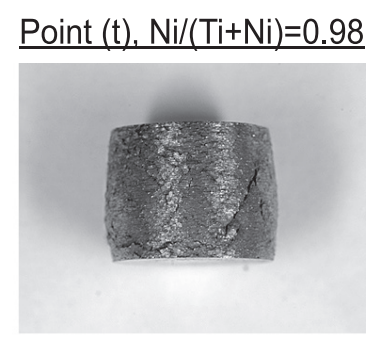

Fracture strain, $\varepsilon_{\mathrm{f}}=26 \%$

Point $(\mathrm{g}), \mathrm{Ni} /(\mathrm{Ti}+\mathrm{Ni})=1.00$

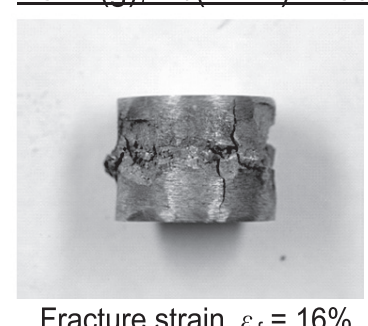

Fracture strain, $\varepsilon_{\mathrm{f}}=16 \%$
Fig. 15 Macro view of synthesized products after compression test.

$\mathrm{Ni}_{3} \mathrm{Al}$ への $\mathrm{Ti}$ 添加が有効な理由は, 例えば合成体の $\mathrm{O}_{2}, \mathrm{~N}_{2}$, $\mathrm{H}_{2} \mathrm{O}$ 量が考えられる. 燃焼合成では出発物質として微粉末を 用いるので, 粉末の表面積が大きく, 湿気や吸着ガスを含み 易い．また圧粉体には気孔があり，空気も含んでいる．これ らガスは, 大半は燃焼合成時に圧粉体から放出されるが14,15), 燃燒合成では秒単位で合成体を急速緻密化させるため, 条件 次第では合成体にガスが残留し,かつガスと粉末が反応する ことが考えられる．Tiを添加することで，

$$
\begin{aligned}
& \mathrm{Ti}(\mathrm{s})+\frac{1}{2} \mathrm{O}_{2}(\mathrm{~g})=\mathrm{TiO}(\mathrm{s}) \\
& \mathrm{Ti}(\mathrm{s})+\frac{1}{2} \mathrm{~N}_{2}(\mathrm{~g})=\operatorname{TiN}(\mathrm{s})
\end{aligned}
$$

あるいは, $\mathrm{Ti}$ と $\mathrm{H}_{2} \mathrm{O}$ の水熱反応によって ${ }^{16)}$,

$$
\mathrm{Ti}(\mathrm{s})+\mathrm{H}_{2} \mathrm{O}(\mathrm{g})=\mathrm{TiO}(\mathrm{s})+\mathrm{H}_{2}(\mathrm{~g})
$$

これら反応の結果, $\mathrm{Ni}_{3} \mathrm{Al}$ に固溶する $\mathrm{O}, \underline{\mathrm{N}}$ 量が減少し，そ の結果, $\mathrm{Ni}_{3} \mathrm{Al}$ の延性が向上したことが考えられる.

また文献によれば, $\mathrm{Ni}_{3} \mathrm{Al}$ の脆さの原因は粒界脆性であり, この粒界脆性は環境中の水分で引き起こされると報告されて いる ${ }^{17)}$. この報告から考光れば， $\mathrm{Ni}_{3} \mathrm{Al} へ$ へ $\mathrm{Ti}$ 添加は，上記 (3) 式のように, $\mathrm{Ni}_{3} \mathrm{Al}$ 粒界の $\mathrm{H}_{2} \mathrm{O}$ 量を低隇し, 粒界脆性を改 善するうえで，役立ったとも考えられる。こうした $\mathrm{Ni}_{3} \mathrm{Al}$ の 固溶ガスや，粒界に作用する $\mathrm{H}_{2} \mathrm{O}$ の影響を明らかにするうえ で, 今後, 燃焼合成体について, $\mathrm{O}_{2}, \mathrm{~N}_{2}, \mathrm{H}_{2} \mathrm{O}$ 量を精密分析す ることが望まれる。

一方, $\mathrm{Ti}$ 添加に伴って, $\mathrm{Ni}_{3} \mathrm{Al}$ の結晶そのものの延性が向 上したことも考えられる. $\mathrm{Ni}_{3} \mathrm{Al}$ へ $\mathrm{Ti}$ を添加した場合, $\mathrm{Ti}$ 原 子は $\mathrm{Al}$ 原子と置換すると言われる ${ }^{18)}$. これは $\mathrm{Ti}-\mathrm{Ni}-\mathrm{Al}$ 三元 系状態図に扔いて, $\mathrm{Ni}_{3} \mathrm{Al}$ の固溶範囲が $\mathrm{Al}$ 減少かつ $\mathrm{Ti}$ 増加方
向へ広がることと一致する ${ }^{133} \cdot \mathrm{Ni}_{3} \mathrm{Al}$ では遷移金属の添加に よって, A1原子と置換して共有結合性を下げ, 機械的性質が 改善されるとの報告があるので ${ }^{19}$, Tiを添加することでNi $\mathrm{N}_{3} \mathrm{Al}$ 結晶そのものの延性が改善されたことも考えられる. 金属間 化合物の工業的な加工技術面から見ても, $\mathrm{Ni}_{3} \mathrm{Al}$ の加工性は劣 り, 塑性加工のためには特殊な方法を必要とする20)。これに 対して, NiTi は塑性加工性を有し, 線引加工や圧延加工に よって, ワイヤー材やシート材が得られている. $\mathrm{Ni}_{3} \mathrm{Al}$ 結晶に おいて, $\mathrm{Al}$ 原子の一部が Tiに置き換わったことで, $\mathrm{Ni}_{3} \mathrm{Al}$ 結 晶そのものの延性が向上したことが考えられる．ただし， $\mathrm{Ni}_{3} \mathrm{Al}$ と $\mathrm{NiTi}$ では結晶系が全く異なり $\left(\mathrm{Ni}_{3} \mathrm{Al}\right.$ : 面心立方系, NiTi: 体心立方系), かつ金属間化合物の塑性変形では, 結晶 格子のすべり面が関係するため, $\mathrm{Ni}_{3} \mathrm{Al} へ$ へ Ti 添加の効果に ついては，今後さらに検討する必要がある.

$\mathrm{Ni}_{3} \mathrm{Al}$ の延性改善策としては, B添加が世界的に有名である ${ }^{1}$. 周知のように $\mathrm{Ni}_{3} \mathrm{Al}$ に B 添加すると, $\mathrm{Ni}_{3} \mathrm{Al}$ の粒界の脆さが 改善され, 延性が劇的に向上する. 以前, 著者が行った B 添 加 $\mathrm{Ni}_{3} \mathrm{Al}$ の燃焼合成においても, 明らかに合成体の延性が向

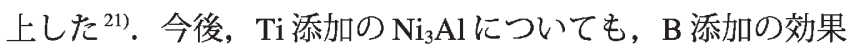
を調べる必要がある。

\section{4 まとめ}

本研究では, $\mathrm{TiAl}-\mathrm{Ni}_{3} \mathrm{Al}$ 複合金属間化合物を燃焼合成させ た場合に生じがちな $\mathrm{Ti}_{2} \mathrm{NiAl}_{3}\left(\tau_{3}\right)$ 相や $\mathrm{TiNi}_{2} \mathrm{Al}\left(\tau_{4}\right)$ 相を避ける 目的から, Ti-Ni-Al 三元系組成図の $\mathrm{TiAl}$ 近傍, $\mathrm{Ni}_{3} \mathrm{Al}$ 近傍で の二段階燃焼合成を試みた。

(1) 二段階燃焼合成法により, Ti-Ni-Al 三元系組成図の TiAl 近傍および, $\mathrm{Ni}_{3} \mathrm{Al}$ 近傍の化合物を作製できた.

(2) TiAl 近傍の合成体は, $\mathrm{TiAl}$ 相 $+\mathrm{Ti}_{3} \mathrm{Al}$ 相 $+\mathrm{Ti}_{2} \mathrm{NiAl}_{3}\left(\tau_{3}\right)$ 相か らなり, 圧縮試験からこの合成体は脆く硬く, 構造用材料 として適さぬことが分かった。組織観察, 相分析から, $\mathrm{Ti}_{2} \mathrm{NiAl}_{3}\left(\tau_{3}\right)$ 相が機械的性質を悪化させる原因と考元られ た.

(3) $\mathrm{Ni}_{3} \mathrm{Al}$ 近傍の合成体は, $\mathrm{Ni}_{3} \mathrm{Al}$ 相 $+\mathrm{NiAl}$ 相，あるいは $\mathrm{Ni}_{3} \mathrm{Al}$ 単相からなり, 圧縮試験から, $\mathrm{Ni}_{3} \mathrm{~A} \mathrm{~A}$ への微量のTi添加は, 延性改善のうえで効果的なことが分かった. $\mathrm{Ni}_{3} \mathrm{Al} へ の \mathrm{Ti}$ 添加によって, 合成体の $\mathrm{O}_{2}, \mathrm{~N}_{2}, \mathrm{H}_{2} \mathrm{O}$ 量を低減し, また $\mathrm{Ni}_{3} \mathrm{Al}$ 結晶の $\mathrm{Al}$ 原子と $\mathrm{Ti}$ 原子が置換して, 合成体の延性を向上 させたと考光られる。

(4) $\mathrm{Ni}_{3} \mathrm{Al}$ の延性改善策としては, B の添加が良く知られてお

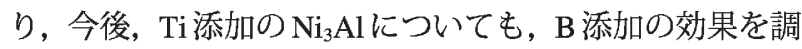
べる必要がある。

\section{文献}

1) K. Aoki, O. Izumi: "On the Ductility of the Intermetallic Compound $\mathrm{Ni}_{3} \mathrm{Al}^{\prime}$, J. Japan Inst. Metals, 41 (1977) 170-175.

2) K. Ito, T. Hayashi, T. Murakami, H. Numakura: "Mechanical and Functional Properties of Mo-Si-B Ternary Alloys for Ultrahigh Temperature Applications", Materia Japan, 44(2005)131- 
137.

3) M. Yamaguchi: "Intermetallic Compounds -High-Temperature Materials for the 21 st Century-", Materia Japan, 35(1996) 10541117.

4) T. Tetsui: "Characteristics of TiAl as a High-Temperature Structural Material and Practical Application Efforts Centered on Turbochargers for passenger Vehicles", J. Japan Inst. Metals, 64(2000)971-976.

5) W. J. Buehler, J. V. Gilfrich, R. C. Wiley: "Effect of LowTemperature Phase Changes on the Mechanical Properties of Alloys near Composition TiNi", J. Appl. Phys., 34(1963) 1475.

6) J. J. Reilly, R. H. Wiswall: "Formation and Properties of Iron Titanium Hydride”, Inorg. Chem., 13(1974)218-222.

7) Y. Kaneko, F. Kuniyoshi: "High Performance NdFeB Sintered Magnets and Their Applications", J. Jpn. Soc. Powder Powder Metallurgy, 53(2006)573-578.

8) K. Tachikawa, M. Yamaguchi, H. Sasaki, T. Ando, T. Takeuchi: "Structure and Performance of $\mathrm{Nb}_{3} \mathrm{Sn}$ Superconducting Wires Prepared from Sn-Based Alloy Sheets", J. Japan Inst. Metals, 74(2010)460-460.

9) K. Yoshimi, H. Hosoda, T. Nakano: "Novel Research Fields Derived from the study on Intermetallic Compounds, -From Green Innovation to Life Innovation-", Materia Japan, 51 (2012) 168-178.

10) A. Hibino, O. Komaki: "Fabrication of Ti-Ni-Al Intermetallic Compounds by Two-Step Combustion Synthesis Process", J. Jpn. Soc. Powder Powder Metallurgy, 60(2013)441-450.

11) S. Takeuchi, Y. Hirabayashi, A. Hibino: "Synthesized Phases and Microstructure of $\mathrm{TiAl}-\mathrm{Ni}_{3} \mathrm{Al}$ Composite Intermetallic Compounds by Two-Step Combustion Synthesis", J. Jpn. Soc. Powder Powder Metallurgy, 61(2014)73-81.

12) A. Hibino, Y. Sumiyoshi, K. Hayashi: "Fabrication of Ti-Ni-
A1 Intermetallic Compounds by Combustion Synthesis Process and their Mechanical Properties", J. Jpn. Soc. Powder Powder Metallurgy, 58(2011)625-632.

13) V. Raghavan: "Al-Ni-Ti (Aluminum-Nickel-Titanium)", Journal of Phase Equilibriua and Diffusion, 26(2005)268-272.

14) A. Hibino, M. Kiuchi: "Pressureless Combustion Synthesis of Dense TiAl Intermetallic Compounds by $\mathrm{Ni} / \mathrm{Al}$ powder Addition", Marerials Transactions JM, 40(1999)92-99.

15) A. Hibino: "Pressure Less Combustion Synthesis of $\mathrm{Ni}_{3} \mathrm{Al}$ Intermetallic Compound", J. Jpn. Soc. Powder Powder Metallurgy, 42(1995) 1264-1269.

16) M. Yoshimura, H. Ohira, S. Somiya: "Hydrothermal Oxidation of Titanium Metal", The Ceramic Society of Japan, 93(1985) 357-363.

17) E. P. George, C. T. Liu, D. P. Pope: "Environmental Embrittlement: The Major Cause of Room-Temperature Brittleness in Polycrystalline $\mathrm{Ni}_{3} \mathrm{Al}^{\prime}$, Scripta Metallurgica et Materialia, 27(1992)365-370.

18) R. D. Rawlings, A. E. Staton-Bevan: "The Alloying Behaviour and Mechanical Properties of Polycrystalline $\mathrm{Ni}_{3} \mathrm{AI}$ ( $\gamma^{\prime}$ phase) with Ternary Additions", J. of Materials Science, 10(1975) 505-514.

19) T. Takasugi, O. Izumi, N. Masahashi: "Electronic and Structural Studies of Grain Boundary Strength and Fracture in $\mathbf{L l}_{2}$ Ordered Alloys-II. On The Effect of Third Elements in $\mathrm{Ni}_{3} \mathrm{Al}$ Alloy", Acta Metallurgica, 33(1985)1259-1269.

20) T. Hirano: "Improvement of room temperature ductility of stoichiometric $\mathrm{Ni}_{3} \mathrm{Al}$ by unidirectional solidification", Acta Metallurgica et Materialia, 38(1990)2667-2671.

21) A. Hibino, M. Kiuchi: "Pressure Less Combustion Synthesis of B Added $\mathrm{Ni}_{3} \mathrm{Al}$ Intermetallic Compound", J. Jpn. Soc. Powder Powder Metallurgy, 42(1995) 1270-1276. 